J. W. Argyle has continued his field work among the Soli, to the east of Lusaka, while at the same time collecting data on the urbanized Soli in Lusaka. This project will be written up next year.

A study in rural economics was launched among the Bemba to discover how far the village economy is supported by local agriculture and other rural activities, and to what extent it is dependent on the remittances from the copper mines and other sources of employment. As in some villages up to 70 per cent. of the adult male population is absent at work, it was considered that a woman would be better able to conduct the field work, which perforce involves inquiry largely among the Bemba women. Miss Tweedie was appointed and has since built up a team of assistants who are collecting household budgets in the villages, no easy task where most of the local produce and much of the wealth remitted from the employment areas is in kind and not in cash.

Dr. R. J. Apthorpe, the Research Secretary, has devoted considerable time, both in field trips and in inquiries from local informants, to the clan organization of the Nsenga, and it is hoped that the material will shortly be ready for publication. The Institute's work in Nyasaland gave Dr. Apthorpe the chance to do some comparative work on the clan organization in the Blantyre-Limbe area.

In connexion with a CCTA inquiry into Absenteeism and Labour Turnover, the Institute has undertaken the collection of data in Northern and Southern Rhodesia. R. Burnett, with previous personnel experience on the Copperbelt and in Salisbury, is conducting this work, assisted by three African assistants.

The latest recruit to the staff is George Kay, who is engaged on inquiries in the Luapula Province of Northern Rhodesia, in connexion with the Fort Rosebery Health and Nutrition Scheme; it is hoped that the observations of a trained geographer will provide data on which the progress of the scheme can be accurately assessed.

The Institute is also assisting a number of affiliates and associated workers. Dr. and Mme Roumeguère, holders of an International African Institute grant, have returned to France after a year's field work in Southern Rhodesia. R. Rotberg, an historian of Princeton and currently a Rhodes Scholar, is studying the part played by the Christian Missions in the development of Northern Rhodesia. M. Miracle, from the Nutrition Research Institute at Stanford University, California, is engaged on a study of the role of maize in African agriculture, while Dr. M. Cole, of the University College of North Staffordshire, spent a long vacation (1959) working on certain aspects of the ecology, particularly in relation to the brachystegia woodlands. Finally, in September, Dr. Dotson, a Fulbright scholar, began his study of the Asian communities of the Federation.

[Communicated by H. A. Fosbrooke, Director, Rhodes-Livingstone Institute]

\title{
The Diaries of Richard Thornton
}

A most valuable addition to records of African exploration is shortly to be published, in the diaries kept by the young geologist, Richard Thornton.

Thornton's first appointment was to Livingstone's expedition of 1858 , one of the objectives of which was to investigate the coal deposits in the neighbourhood of Tete on the Zambezi. He was soon dismissed by Livingstone, however, and went to Zanzibar, where he joined the expedition which Baton von der Decken was preparing to verify the report of Rebmann (1848), not fully accepted in contemporary scientific circles, that snow-clad mountains existed on and near the Equator in eastern Africa. After spending May to November 1861 with von der Decken on his Kilimanjaro expedition, Thornton became reconciled with Livingstone and rejoined him in the Zambezi in April I862. After further mapping and geological work on the Zambezi and Shire, Thornton died at Shupanga on 21 April 1863. 
A rich store of Thornton's letters and diaries is in the possession of the Bodleian, held by the Rhodes House Library at Oxford, and further papers are to be found in the Archives in Salisbury, Southern Rhodesia. These sources are supplemented by Thornton's diaries covering both his East African and Zambezi work in the possession of the Rhodes-Livingstone Museum at Livingstone, Northern Rhodesia.

The Kilimanjaro diary was prepared for publication by Thornton's brother George, even to the extent of commissioning Thomas Baines to paint the frontispiece, but the executors of von der Decken invoked the terms of the agreement between the two explorers to prohibit its publication. H. A. Fosbrooke has now undertaken the editing of this diary, which it is hoped to issue next year, sponsored by the Rhodes-Livingstone Museum and published by Chatto \& Windus, in the new 'Robins Series' of works on Central and Southern Africa. The Zambezi diaries are being edited by J. H. Chaplin, Inspector of Monuments, Northern Rhodesia, and will be published in the same series.

[Communicated by H. A. Fosbrooke, Director, Rhodes-Livingstone Institute]

\section{The Historical Society of Nigeria, Fifth Annual Congress}

TuE Fifth Annual Congress of the Historical Society of Nigeria was held at Enugu on 20, 21 , and 22 December 1959. The theme of the Congress was 'Nigerian History'. It is hoped to publish a more detailed account of the Congress in a forthcoming issue of Africa.

\section{Ford Foundation Grant to the East African Institute of Social Research, Makerere College}

THE Ford Foundation has made a grant for assistance to the East African Institute of Social Research, in the establishment of an Applied Research Unit. The Institute's staff and its associated research workers have been engaged for over ten years in numerous studies designed to increase knowledge of social and economic conditions in East Africa, and the central task of the Institute will continue to be basic research of this type which, in addition to increasing the store of fundamental knowledge available, often provides information of immediate practical use. An additional need exists, however, for the solution of specific problems which arise for Central and Local Governments, industrial organizations, and other bodies concerned with developments in East Africa. The new Unit will be particularly concerned with this type of research, which has a definite practical objective.

The grant will make possible the appointment of a Research Secretary and three research workers for a period of at least three years, and it is hoped that the results of the work of the Applied Research Unit will be such that it will be enabled to continue its work, after the end of the Ford Foundation Grant, with assistance from the various governments and private bodies who may use the Unit.

\section{Training in Community Development}

The Ghana Government proposes to renew its offer of four fellowships and two scholarships for training in community development. The training will start early in March 1960: that provided under the fellowships lasting six months, and under the scholarships a year. It will be mainly practical, consisting of attachment to the Department of Social Welfare and Community Development in Ghana. Particulars of the I959 training programme, which will form the model for the I960 programme, are given below.

The 1960 awards will be made by the Government of Ghana to persons nominated by the governments of their respective countries. Candidates for the fellowships should already possess some experience as government officials, of working with rural people, and some knowledge of, and interest in, the principles of community development. They should 